\title{
Hysteresis response of daytime net ecosystem exchange during drought
}

\author{
N. Pingintha ${ }^{1,3}$, M. Y. Leclerc ${ }^{1}$, J. P. Beasley Jr. ${ }^{2}$, D. Durden ${ }^{1}$, G. Zhang ${ }^{1}$, C. Senthong ${ }^{3}$, and D. Rowland ${ }^{4}$ \\ ${ }^{1}$ Lab for Environmental Physics, The University of Georgia, 1109 Experiment Street, Griffin, Georgia 30223, USA \\ ${ }^{2}$ Crop and Soil Sciences Department, The University of Georgia, P. O. Box 1209, Tifton, Georgia 31793, USA \\ ${ }^{3}$ Department of Agronomy, Faculty of Agriculture, Chiang Mai University, 239 Huaykaew Road, Suthep, \\ Chiang Mai 50200, Thailand \\ ${ }^{4}$ US Department of Agriculture/Agricultural Research Service, National Peanut Lab, Dawson, Georgia 39842, USA
}

Received: 16 September 2009 - Published in Biogeosciences Discuss.: 17 November 2009

Revised: 24 March 2010 - Accepted: 25 March 2010 - Published: 31 March 2010

\begin{abstract}
Continuous measurements of net ecosystem $\mathrm{CO}_{2}$ exchange (NEE) using the eddy-covariance method were made over an agricultural ecosystem in the southeastern US. During optimum environmental conditions, photosynthetically active radiation (PAR) was the primary driver controlling daytime NEE, accounting for as much as 67 to $89 \%$ of the variation in NEE. However, soil water content became the dominant factor limiting the NEE-PAR response during the peak growth stage. NEE was significantly depressed when high PAR values coincided with very low soil water content. The presence of a counter-clockwise hysteresis of daytime NEE with PAR was observed during periods of water stress. This is a result of the stomatal closure control of photosynthesis at high vapor pressure deficit and enhanced respiration at high temperature. This result is significant since this hysteresis effect limits the range of applicability of the Michaelis-Menten equation and other related expressions in the determination of daytime NEE as a function of PAR. The systematic presence of hysteresis in the response of NEE to PAR suggests that the gap-filling technique based on a nonlinear regression approach should take into account the presence of water-limited field conditions. Including this step is therefore likely to improve current evaluation of ecosystem response to increased precipitation variability arising from climatic changes.
\end{abstract}

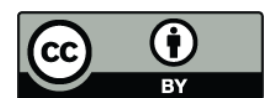

Correspondence to: $\mathrm{M}$. Y. Leclerc (mleclerc@uga.edu)

\section{Introduction}

Concerns over global climate change have generated an effort to understand how environmental changes, such as those seen in temperature and precipitation, influence net carbon exchange between terrestrial ecosystems and the atmosphere. In addition to changes in average temperature and precipitation, the Intergovernmental Panel on Climate Change (IPCC) expects the occurrence of extreme weather events (i.e. drought and flood) to become more frequent and/or intense (IPCC, 2007). The anticipated increase in both climate variability and extreme events is presumed to adversely affect plant growth and water availability. Everything else being constant, an increase in the number of hot days increases potential evapotranspiration leading to drought. Hence, a mechanistic understanding of how drought influences carbon exchange between ecosystems and the atmosphere is a sine qua non condition to anticipate possible impact of climate change scenarios. Such results can also provide the modeling community with a better basis to improve and validate their models.

The net ecosystem exchange of $\mathrm{CO}_{2}$ (hereafter referred to as NEE) relies on the balance between $\mathrm{CO}_{2}$ uptake through plant photosynthesis and $\mathrm{CO}_{2}$ emission through plant and soil respiration generally referred to as ecosystem respiration (Chapin et al., 2006). The NEE can be measured directly using the eddy-covariance method (hereafter referred to as EC), which provides a spatially integrated net carbon exchange on a continuous basis with minimal disturbance to the surrounding vegetation (Aubinet et al., 2000; Baldocchi et al., 2001). With these continuous measurements, the derivation of annual sums of NEE then becomes possible. However, due to

Published by Copernicus Publications on behalf of the European Geosciences Union. 
a combination of inherent limitations in the applicability of the measurement method and related data robustness, both data rejection and missing data are unavoidable. This data loss can be as much as $65-75 \%$ of a dataset spanning all seasons (Baldocchi et al., 2001; Falge et al., 2001; Law et al., 2002). Large resulting gaps in the dataset must be reconstructed using several methods based on varying degrees of empiricism to obtain a seasonal carbon balance. For instance, gap-filling techniques are based on a wide range of standard procedures, including linear interpolation (Falge et al., 2001), look-up tables (Falge et al., 2001), moving averages (Falge et al., 2001; Reichstein et al., 2005), non-linear regressions (Goulden, 1996; Falge et al., 2001; Suyker and Verma, 2001), artificial neural networks (Papale and Valentini, 2003; Papale et al., 2006), mechanistic models (Braswell et al., 2005; Ooba et al., 2006), and the multiple imputation method (Hui et al., 2004).

However, one of the conventional methods to replace missing data in NEE data in daytime conditions has been to resort to the use of non-linear regressions (Falge et al., 2001; Ooba et al., 2006). This approach is based on parameterized non-linear equations (e.g. Michaelis-Menten equation) to quantify the relationship between NEE and radiation (e.g. photosynthetically active radiation; hereafter referred to as PAR). While the failure using a non-linear equation to describe daytime NEE only as a function of radiation has been previously observed in various ecosystems ( $\mathrm{Li}$ et al., 2005; Serrano-Ortiz et al., 2007; Holst et al., 2008; Wang et al., 2008), to date a mechanistic explanation is still missing.

Peanut (Arachis hypogaea L.) is a major crop grown under both rainfed and irrigated conditions in the southeastern US. Typically, peanut plants have to cope with unfavorable environmental factors such as high temperature, low soil moisture, and high vapor pressure deficit (hereafter referred to as VPD) often resulting in drought stress. Drought affects nearly all aspects of plant growth and most physiological processes; however, the stress response depends on intensity, rate, duration, and the stage of plant growth. Inconsistent effects of these environmental stresses on physiological depression have been reported in previous studies (e.g. Bhagsari et al., 1976; Nautiyal et al., 1995; review by Reddy et al., 2003; Lauriano et al., 2004). Drought stress also alters the development of leaf area and changes the plant physiology. As the cumulative deficit in soil water grows, plants close their stomates to prevent further water loss through transpiration (Reddy et al., 2003). As a consequence, the $\mathrm{CO}_{2}$ assimilation is also reduced. The long-term effect of soil water deficit on canopy assimilation is a reduction in leaf area. Drought reduces leaf area by folding, wilting, slowing leaf expansion, and shutting off the supply of carbohydrates (Clifford et al., 1993; Collino et al., 2001; Reddy et al., 2003). The consequent reduction in leaf area reduces plant's ability to capture light resources (Chapman et al., 1993a; Collino et al., 2001), resulting in a negative influence on biomass.
Measurements made in most of the above studies were conducted at the leaf scale, e.g. clamp-on leaf chambers, (Nautiyal et al., 1995; Bhagsari et al., 1976; Lauriano et al., 2004). There is still a lack of information on a continuous basis on the effect of drought stress on carbon exchange at the canopy scale. To this end, EC flux measurements were carried out in a rainfed peanut field. The objectives of the present study are to 1 . examine the influence of drought stress on daytime NEE and 2. to explain the inadequacy of the Michaelis-Menten equation in describing the NEE-PAR relationship.

\section{Materials and methods}

\subsection{Site description}

The experiment was conducted in a non-irrigated peanut field located in Unadilla, Georgia, USA $\left(32^{\circ} 10^{\prime} 39.72^{\prime \prime} \mathrm{N}\right.$, $83^{\circ} 38^{\prime} 24.48^{\prime \prime} \mathrm{W}$ ) in 2007 . The area is flat with a slope less than $2 \%$ and large enough to provide at least $210 \mathrm{~m}$ fetch in all directions. The top $10 \mathrm{~cm}$ of soil is classified as sandy loam, composed of $74 \%$ of sand, $16 \%$ of silt, and $10 \%$ of clay with a bulk density of $1.19 \mathrm{~g} \mathrm{~cm}^{-3}$. The field capacity was $0.118 \mathrm{~m}^{3} \mathrm{~m}^{-3}$ and the permanent wilting point was $0.042 \mathrm{~m}^{3} \mathrm{~m}^{-3}$. Total carbon and nitrogen content of soil were 0.43 and $0.03 \%$, respectively.

Fertilizer (N:P:K) was applied on day of year (hereafter referred to as DOY) 93 at a rate of $336 \mathrm{~kg} \mathrm{ha}^{-1}$. Peanut was planted with $6.6 \mathrm{~kg} \mathrm{ha}^{-1}$ of phorate on DOY 125 . Traditional herbicides including Gramoxone (1, 1-dimethyl-4, 4 bipyridinium) at $1.75 \mathrm{~L} \mathrm{ha}^{-1}$, Storm (bentazon and acifluorfen) at $1.17 \mathrm{~L} \mathrm{ha}^{-1}$, and 2, 4-DB (4-(2, 4-dichlorophenoxy) butyric acid) at $0.44 \mathrm{~L} \mathrm{ha}^{-1}$ were applied on DOY 157 based on the typical peanut weed control program the Southeast. Leaf spot and white mold were controlled using Bravo Ultrex (on DOY 197, DOY 232, and DOY 253) and Headline 2.09EC (on DOY 1176 and DOY 211). Peanut was harvested on DOY 283 with a yield of $4783 \mathrm{~kg} \mathrm{ha}^{-1}$.

\subsection{Field measurements and data processing}

Fluxes of carbon dioxide, water vapor, heat and momentum were continuously measured using EC method from DOY 172 to DOY 271. The flux system was mounted at $1.5 \mathrm{~m}$ above the ground and consisted of a fast response 3dimensional sonic anemometer (CSAT3, Campbell Scientific, Logan, UT) and a fast response open-path $\mathrm{CO}_{2} / \mathrm{H}_{2} \mathrm{O}$ infrared gas analyzer (IRGA, Li 7500, Li-Cor Inc., Lincoln, $\mathrm{NE}$ ). The IRGA was placed with a $30^{\circ}$ tilt angle to minimize accumulation of dust and water droplets on the windows. Calibration of the IRGA was done prior to the experiment campaign using nitrogen gas and $600 \mathrm{ppm} \mathrm{CO}_{2}$ gas to calibrate the $\mathrm{CO}_{2}$ and water vapor zeros and the span of $\mathrm{CO}_{2}$, respectively. The span of water vapor was calibrated with dew point generator (Li 610, Li-Cor Inc., Lincoln, NE). 
The three wind components, sonic virtual temperature, water vapor, and $\mathrm{CO}_{2}$ density were sampled at rate of $10 \mathrm{~Hz}$. Half-hourly fluxes were calculated on-line and collected by CR1000 dataloggers (Campbell Scientific, Logan, UT). All raw $10 \mathrm{~Hz}$ data were saved to a compact flash card (Sandisk, Sunnyvale, CA) for later reprocessing. The eddy-covariance flux system was powered by two 12 VDC deep cycle batteries that were charged using $120 \mathrm{~W}$ solar panels.

Along with the EC tower, standard meteorological and soil parameters were measured continuously with an array of sensors. Net radiation $(R n)$ was measured using a net radiometer (Model NR-LITE, Kipp and Zonen USA Inc., Bohemia, NY) mounted on the EC tower, $1.8 \mathrm{~m}$ above the ground surface. The canopy temperature was measured at canopy height using a precision infrared thermocouple sensor with an accuracy of $\pm 0.4^{\circ} \mathrm{C}$ (IRTS-P5, Apogee Instrument Inc., Logan, UT). Belowground measurements were made at the base of tower; include soil temperature and volumetric soil water content profiles. Soil temperature at depths of $0.02,0.05,0.08$, and $0.30 \mathrm{~m}$ was measured using a custombuilt chromel-constantan thermocouple. Soil volumetric water content was measured using time domain reflectometry sensors (CS615, Campbell Scientific, Logan, UT) at depths of 0.02 and 0.02 to $0.05 \mathrm{~m}$. The soil heat flux $(G)$ was determined using the averaging of two soil heat plates measurements (HFT-3, Campbell Scientific, Logan, UT). The plates were buried at a depth of $0.08 \mathrm{~m}$ in two distinct locations; one was between peanut rows and the other was within a row. The average temperature of the soil layer above the plate was measured using 4 parallel thermocouples (TCAV, Campbell Scientific, Logan, UT). The thermocouples were placed at the depths of 0.02 and $0.06 \mathrm{~m}$ to obtain the average temperature of the soil layer above each heat flux plate. The total heat flux at the soil surface is then calculated by adding the heat flux measured by the plate to the energy stored in the soil layer. Storage of heat in the soil above the soil heat flux plate was calculated by multiplying the change in soil temperature over the averaging period by the soil heat capacity. The value used for the heat capacity of dry soil was $0.84 \times 10^{-3} \mathrm{~J} \mathrm{~kg}^{-1}$ $\mathrm{K}^{-1}$.

An automatic weather station (ET106, Campbell Scientific, Logan, UT) with 30-min average data output was installed at $2 \mathrm{~m}$ above the ground surface at the study site to measure air temperature, relative humidity, wind speed and wind direction, solar radiation, and precipitation. The station was powered by a $7 \mathrm{Ahr}$ sealed-rechargeable battery that was charged with a $1000 \mathrm{~W}$ solar panel. All meteorological and belowground measurements were averaged over 30-min periods and stored to a datalogger (CR10X, Campbell Scientific, Logan, UT). In addition, the leaf area index (hereafter referred to as LAI) was determined at intervals of 7 to 10 days with an electronic leaf area meter (LAI-2000, Li-Cor Inc., Lincoln, NE) throughout the season. The canopy temperature sensor was replaced on DOY 180. Gaps in solar radiation, temperature, and precipitation data were filled with data from a nearby meteorological station located approximately $8 \mathrm{~km}$. Incident PAR was estimated from solar radiation.

\subsection{Data analysis}

The raw $10 \mathrm{~Hz}$ data from the sonic anemometer and the infrared gas analyzer were checked for spikes before calculating eddy-covariance fluxes. This was done following Vickers and Mahrt (1997). Each individual data point of the threevelocity components from the sonic anemometer was also rotated according to a planar fit rotation to virtually align the sonic anemometer axis along the long-term streamlines (Wilczak et al., 2001). Before half-hourly fluxes of $\mathrm{CO}_{2}$ (NEE), latent heat $(\lambda E)$, and sensible heat $(H)$ were calculated, the time series were linearly detrended. Finally, the flux data were corrected for variations in air density due to fluctuations in water vapor and heat fluxes, i.e. using the Webb, Pearman and Leuning correction (Webb et al., 1980). Data collected during periods with rain or dew was rejected. The analyses were conducted using a $\mathrm{C}++$ program written in-house.

It has been recognized for some time by the flux monitoring community that the EC technique is likely to underestimate eddy fluxes in calm conditions at night, but there is no consensus on how to correct the problem. Most researchers screen nighttime data using a friction velocity $\left(u_{*}\right)$ threshold (Goulden et al., 1997; Aubinet et al., 2000; Reichstein et al., 2005; Papale et al., 2006). Estimation of $u_{*}$ threshold values followed Reichstein et al. (2005) using the online calculation software found at http://gaia.agraria.unitus.it/database/ eddyproc. In calm nights, $78.68 \%$ of the carbon flux data was rejected so nighttime flux data are not presented in this study.

In this study, daytime is defined as the period with solar radiation $>20 \mathrm{~W} \mathrm{~m}^{-2}$. Half-hourly data were fitted using a Michaelis-Menten equation (Michaelis and Menten, 1913) to test the ability of the following model to describe the dependence of NEE $\left(\mu \mathrm{mol} \mathrm{CO} \mathrm{Cm}^{-2} \mathrm{~s}^{-1}\right)$ on solar PAR $\left(\mu\right.$ mol photons $\left.\mathrm{m}^{-2} \mathrm{~s}^{-1}\right)$ :

$\mathrm{NEE}=\frac{\alpha \cdot \mathrm{PAR} \cdot \mathrm{NEE}_{\mathrm{sat}}}{\alpha \cdot \mathrm{PAR}+\mathrm{NEE}_{\mathrm{sat}}}+R_{\mathrm{e}}$

where $\alpha$ is the apparent quantum yield or the initial slope of the light response curve ( $\mu \mathrm{mol} \mathrm{CO} 2 \mu \mathrm{mol}^{-1}$ photons), $\mathrm{NEE}_{\mathrm{sat}}$ is the saturation value of NEE at an infinite light level, and $R_{\mathrm{e}}$ is the ecosystem respiration in daytime conditions.

The canopy conductance was used to assess stomatal control on $\mathrm{CO}_{2}$ gas exchange and evapotranspiration. With no independent measurements of transpiration or soil evaporation available in this study, a clean separation of the two components is not possible with EC measurements. Therefore, half-hourly surface conductance (hereafter referred to 
as $g_{\mathrm{s}}$ ) was calculated by rearranging the Penman-Monteith equation (Monteith and Unsworth, 1990):

$\frac{1}{g_{\mathrm{s}}}=\left[\left(\frac{\Delta}{\gamma}\right) \beta-1\right]\left(\frac{1}{g_{\mathrm{a}}}\right)+\frac{\rho \cdot C_{\mathrm{p}} \cdot \mathrm{VPD}}{\gamma \cdot \lambda \cdot E}$,

where $\Delta$ is the rate of change of saturation vapor pressure with temperature, $\gamma$ the psychometric constant, $\beta$ the Bowen ratio which is $H / \lambda E, \rho$ and $C_{\mathrm{p}}$ the density and specific heat of air, respectively, VPD the vapor pressure deficit which is calculated from air temperature and relative humidity data, and $g_{\text {a }}$ the aerodynamic conductance was obtained from sonic anemometer output as (Monteith and Unsworth, 1990):

$$
\frac{1}{g_{\mathrm{a}}}=\frac{u}{u_{*}^{2}}+6.2 \cdot u_{*}^{-0.67}
$$

where $u$ is the mean wind speed.

We examined the energy balance closure which is often considered to be an independent method to assess the reliability of the EC measurements (Wilson, 2002; Aires, 2008). The energy balance closure was tested using a linear regression between the amount of the available energy $(R n-G)$ and the sum of sensible heat and latent heat fluxes $(H+\lambda E)$ using half-hourly data collected during the experiment. The relationship we found was: $(H+\lambda E)=$ $0.74(R n-G)+7.22$, with $R^{2}=0.96$. This result suggests that the EC measurements underestimate $H+\lambda E$ by $26 \%$. Although, the energy balance closure is not perfect, it is typical of the range found at other flux sites. In a comparison of the energy balance closure of 22 FLUXNET sites, Wilson et al. (2002) reported slope, intercept and $R^{2}$ ranging, respectively, between 0.53 and $0.99,-32.9$ and $36.9 \mathrm{~W} \mathrm{~m}^{-2}$, and 0.64 and 0.36 without any effect of vegetation height. In the present study, one of the apparent causes for the imbalance may relate to different source scales of measurements in $R n$ and $G$ compared to $H$ and $\lambda E$ (Schmid, 1994; Wilson, 2002). The net radiometer and soil heat flux plates measure radiation exchange from a relatively small portion of the landscape near the measurement tower, while EC measurements represents an area hundreds of meters square in area (Schmid, 1994). Other possible source of errors lie in the contribution of sub-mesoscale eddies to sensible and latent heat fluxes, choice of the $u_{*}$ threshold, and non-inclusion of the heat storage between the measurement level and the ground. Meyers and Hollinger (2004) found that including the heat storage between the measurement level and the ground, as well as the ground heat storage above the plate in the energy balance of a maize crop and a soybean crop, increase the regression slopes of $3 \%$ to $6 \%$.

\section{Results and discussion}

\subsection{Seasonal variation in environmental conditions and leaf area index}

Over the study period, seasonal trends of soil and canopy temperatures followed a pattern similar to that of air temperature (hereafter referred to as $T_{\mathrm{a}}$ ). Daily average of soil, canopy and, air temperature varied from 21.7 to $31.7^{\circ} \mathrm{C}$, 20.6 to $33.7^{\circ} \mathrm{C}$, and 19.4 to $31.2^{\circ} \mathrm{C}$, respectively. The canopy temperature was slightly higher than the soil and air temperatures. However, maximum values were observed on DOY 222 (Fig. 1a). The total rainfall at the site was $328 \mathrm{~mm}$ (Fig. 1b). Soil water content (hereafter referred to as SWC) followed patterns of precipitation. Maximum daily average SWC $\left(0.135 \mathrm{~m}^{3} \mathrm{~m}^{-3}\right)$ across the upper soil layer $(0.02-0.05 \mathrm{~m})$ occurred on DOY 184. In particular, there was a gradual decrease in soil water content below wilting point $\left(0.042 \mathrm{~m}^{3} \mathrm{~m}^{-3}\right)$ on DOY $217-228$ and DOY 250 255, suggesting that peanut plants may have experienced water stress during those periods (Fig. 1b). LAI rapidly increased during crop development reaching the maximum value of $7.81 \mathrm{~m}^{2} \mathrm{~m}^{-2}$ around DOY 210 . While the minimum LAI of $2.92 \mathrm{~m}^{2} \mathrm{~m}^{-2}$ was found during periods of stress (DOY 217-228), the corresponding LAI reduction is due to either drought-induced limitation of leaf area expansion or temporary leaf wilting or rolling during periods of severe stress (Chapman et al., 1993b; Clifford et al., 1993). With $52 \mathrm{~mm}$ of total precipitation on DOY 235, LAI subsequently recovers reaching the values of $5.06 \mathrm{~m}^{2} \mathrm{~m}^{-2}$ to then steadily decline throughout the end of study period as the plant senesces (Fig. 2).

\subsection{Responses of daytime NEE to PAR}

PAR is the main climatic factor that drives photosynthesis processes. To examine how NEE responds to change in PAR, we use a rectangular hyperbolic Michaelis-Menten function (Eq. 1) to describe the response of NEE averaged over a 30-min period (Fig. 3). In general, peanuts are fast growing so that the functional response of NEE to PAR was determined separately for each growing stage using bins of 7 to 10 consecutive days of data (Table 1). The rectangular hyperbolic function was used successfully to describe the relationship between NEE and PAR. Other than during DOY 219-226 and DOY 227-234, days during which both temperature $\left(32 \pm 4.1\right.$ and $31.5 \pm 4.1^{\circ} \mathrm{C}$, respectively) and VPD $(2.00 \pm 1.18$ and $2.06 \pm 1.19 \mathrm{kPa}$, respectively) were high and SWC $\left(0.037 \pm 0.002\right.$ and $0.048 \pm 0.020 \mathrm{~m}^{3} \mathrm{~m}^{-3}$, respectively) was low (Table 1), the Michaelis-Menten function succeeded in describing the NEE-PAR relationship. Figure 3 shows the large scatter of the data points during these periods should be noted, highlighting the dependence of NEE-PAR relationship on other environmental factors. This will be discussed in greater detail later. 


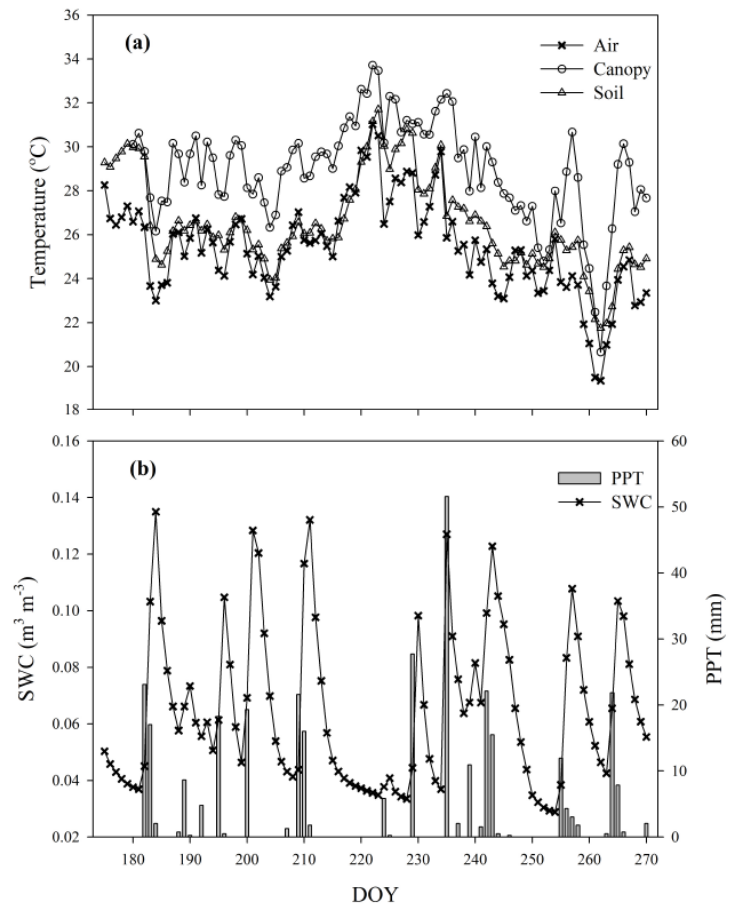

Fig. 1. Seasonal variation in (a) daily average of air temperature, canopy temperature, and soil temperature at the depth of $2 \mathrm{~cm}$; (b) daily average soil water content (SWC) at the depth of $2-5 \mathrm{~cm}$ and daily total precipitation (PTT) over the course of the study. DOY 1 means days of year.

Based on the statistical analysis using Eq. (1), the regression coefficients indicated that the change in PAR accounted for 67 to $89 \%$ of the variations in NEE. The $\alpha$ values varied from -0.0183 to $-0.0438 \mu \mathrm{mol} \mathrm{CO} 2 \mu \mathrm{mol}^{-1}$ photons. This value was well within the range of $\alpha$ reported for crops and grasslands $\left(-0.008\right.$ to $-0.465 \mu \mathrm{mol} \mathrm{CO} 2 \mu \mathrm{mol}^{-1}$ photons; Ruimy et al., 1995; Valentini et al., 1995; Suyker and Verma, 2001; Suyker et al., 2004). The low $\alpha$ at the end of the study was most likely due to late life cycle of the peanut plant, then in its senescent phase.

In order to further examine the dependence of the NEEPAR response on $T_{\mathrm{a}}, \mathrm{VPD}$, and SWC, daytime NEE obtained during the peak growing stage (DOY 201-240) were separated into three $T_{\mathrm{a}}$ classes $\left(T_{\mathrm{a}}<28^{\circ} \mathrm{C}, 28<T_{\mathrm{a}}<\right.$ $32{ }^{\circ} \mathrm{C}$, and $T_{\mathrm{a}}>32^{\circ} \mathrm{C}$ ), three VPD classes (VPD $<1.0 \mathrm{kPa}$, $1.0<\mathrm{VPD}<2.0 \mathrm{kPa}$, and $\mathrm{VPD}>2.0 \mathrm{kPa})$, and three $\mathrm{SWC}$ classes $\quad\left(\mathrm{SWC}<0.04 \mathrm{~m}^{3} \mathrm{~m}^{-3}, \quad 0.04<\mathrm{SWC}<0.07 \mathrm{~m}^{3} \mathrm{~m}^{-3}\right.$, and $\mathrm{SWC}>0.07 \mathrm{~m}^{3} \mathrm{~m}^{-3}$ ) (Fig. $4 \mathrm{a}-\mathrm{c}$ ). Within each group, the NEE data were further subdivided by PAR into

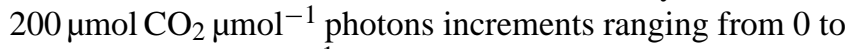
$2200 \mu \mathrm{mol} \mathrm{CO}_{2} \mu_{\mathrm{mol}}{ }^{-1}$ photons and then were bin averaged for each PAR subgroup.

Results showed NEE increased as PAR increased for all temperature conditions (Fig. 4a). These results are in general agreement with previous findings suggesting that peanuts

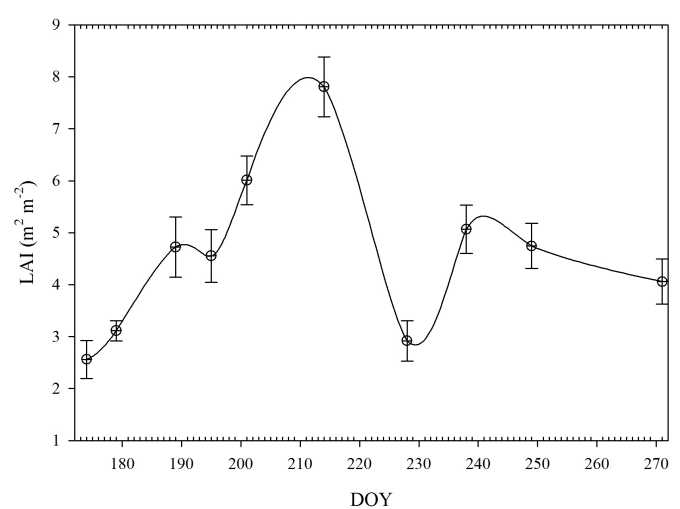

Fig. 2. Seasonal variation in leaf area index $(\mathrm{LAI}) \pm$ standard error over the course of the study.

perform well in the temperature range between 24 to $33^{\circ} \mathrm{C}$ (Saxena et al., 1983). However, at high temperature $\left(T_{\mathrm{a}}>\right.$ $32^{\circ} \mathrm{C}$ ), the NEE was lower than the other two temperature ranges. Similar to $T_{\mathrm{a}}$, NEE increased with PAR increased at all VPD ranges (Fig. 4b). NEE-PAR response curves at $\mathrm{VPD}<1.0 \mathrm{kPa}$ and $1.0<\mathrm{VPD}<2.0 \mathrm{kPa}$ mostly overlapped each other, indicating that there were no significant effects on NEE-PAR relationships between these two VPD ranges. When peanut was subjected to high VPD $(>2.0 \mathrm{kPa})$, NEE was lower than the other two VPD conditions. Unlike $T_{\mathrm{a}}$ and VPD, there were pronounced differences in the light-response curves among different soil water regimes (Fig. 4c). When SWC was not limiting $\left(\mathrm{SWC}>0.04 \mathrm{~m}^{3} \mathrm{~m}^{-3}\right)$, NEE increased with PAR and there was no indication of canopy light saturation. For very low SWC $\left(<0.04 \mathrm{~m}^{3} \mathrm{~m}^{-3}\right)$, NEE increased with PAR at first and then decreased considerably (NEE gets more positive resulted from ecosystem loss carbon to the atmosphere) when PAR exceeded $1300 \mu$ mol photons $\mathrm{m}^{-2} \mathrm{~s}^{-1}$. A reduction in NEE in dry conditions has been observed in different ecosystems (Sims and Bradford, 2001; Hastings et al., 2005; Li et al., 2005; Fu et al., 2006; Aires et al., 2008b; Holst et al., 2008; Wang et al., 2008) and caused by midday stomata closure when irradiance, temperature, and VPD are all high, when the SWC is low (Sims and Bradford, 2001; Li et al., 2005; Aires et al., 2008b) or by enhanced ecosystem respiration at high temperature (Fu et al., 2006; Holst et al., 2008).

\subsection{Response of daytime NEE to water stress}

As discussed above, carbon uptake in this ecosystem results from several factors, including PAR, LAI, $T_{\mathrm{a}}, \mathrm{VPD}$, and SWC. Among these factors, SWC was the dominant factor limiting the NEE-PAR response of peanut during the peak growing stages (Fig. 4c). To illustrate the underlying physiological mechanisms of depression of NEE, we investigated the diurnal course of NEE 
Table 1. Values of parameters in the Michaelis-Menten function (Eq. 1).

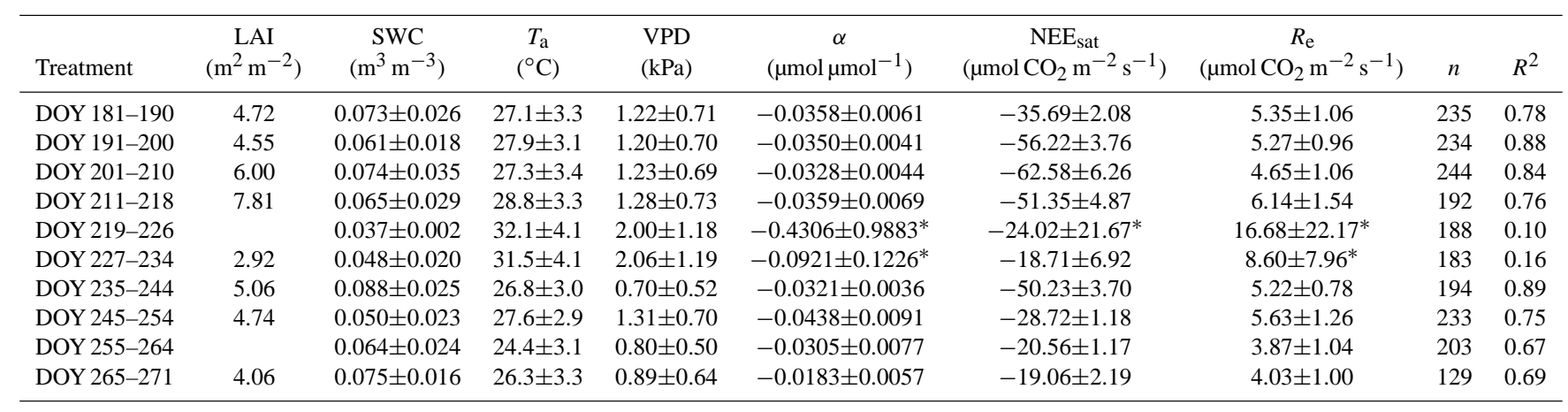

LAI, leaf area index; SWC, soil water content at $2-5 \mathrm{~cm}$ depth; $T_{\mathrm{a}}$, air temperature at $2 \mathrm{~m}$ above the ground; VPD, atmospheric water vapor deficit at $T_{\mathrm{a}} ; \alpha$, the apparent quantum yield; $\mathrm{NEE}_{\mathrm{sat}}$, the saturation value of NEE at an infinite light level not significant; $R_{\mathrm{e}}$, the ecosystem respiration during the daytime; $\mathrm{n}$, observation; and $\mathrm{R}^{2}$, the coefficient of determination;

* not significant at $P \leq 0.05$.
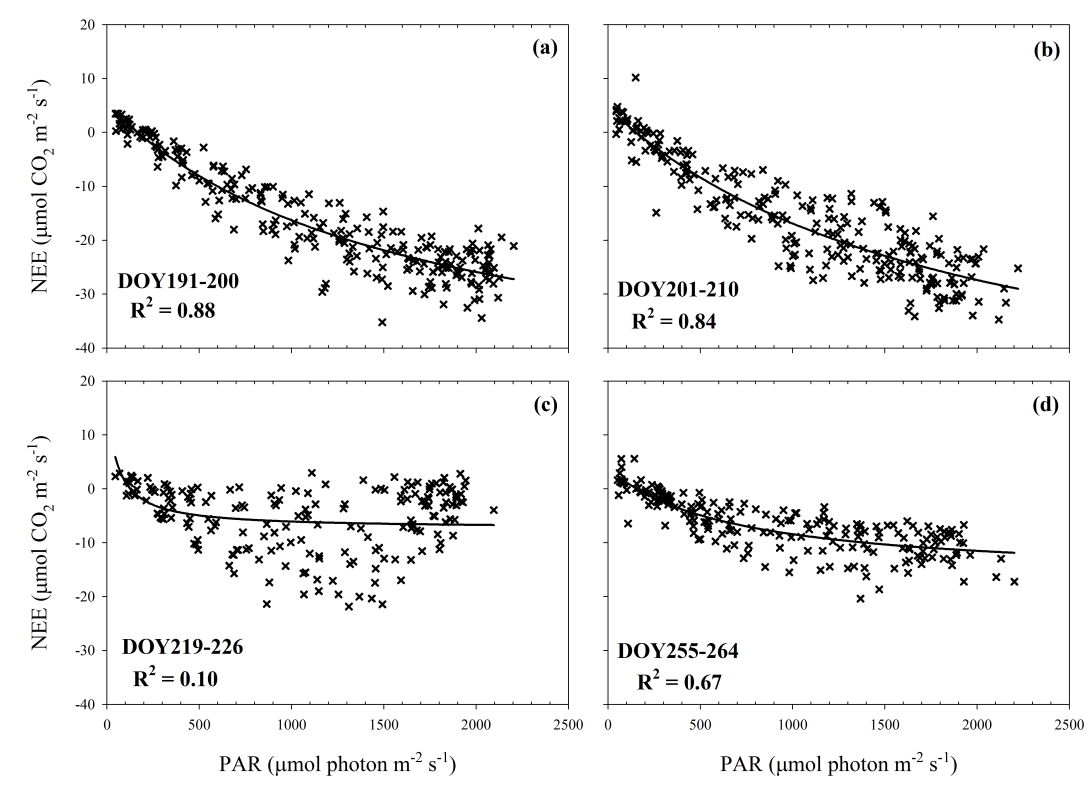

Fig. 3. Example of light-response curves at different growth stages during the study period. The Michaelis-Menten equation as described in Eq. (1) was used to fit the data, and the regression coefficients $\left(R^{2}\right)$ are presented.

and $g_{\mathrm{s}}$ on clear days in two contrasting conditions. During non-stress days, corresponding to an average of SWC of $0.075 \pm 0.026 \mathrm{~m}^{3} \mathrm{~m}^{-3}$, similar trends were observed for $T_{\mathrm{a}}$ and VPD. $T_{\mathrm{a}}$ and VPD increased during the daytime reaching the maximum at $31.7 \pm 1.4^{\circ} \mathrm{C}$ and $2.05 \pm 0.39 \mathrm{kPa}$, respectively, in the late afternoon (Fig. 5a). NEE increased to a maximum of $26.71 \pm 5.72 \mu \mathrm{mol} \mathrm{CO} \mathrm{CO}^{-2} \mathrm{~s}^{-1}$ at about midday and then decreased as the afternoon progressed (Fig. 5b). The maximum $g_{\mathrm{s}}$ appeared around noon, which indicates sufficient water available for the ecosystem (Fig. 5b). During periods with water stress, with the average of SWC of $0.037 \pm 0.002 \mathrm{~m}^{3} \mathrm{~m}^{-3}$, the diurnal course of $T_{\mathrm{a}}$ and VPD were similar to those on the non-stress days, but the maximum values $\left(36.9 \pm 1.6^{\circ} \mathrm{C}\right.$ for $T_{\mathrm{a}}, 3.93 \pm 0.83 \mathrm{kPa}$ for VPD) were much higher than during the non-stress days (Fig. 5c). The diurnal trends of NEE followed a pattern similar to $g_{\mathrm{s}}$, which increased to a maximum $\left(15.98 \pm 3.16 \mu \mathrm{mol} \mathrm{CO}_{2} \mathrm{~m}^{-2} \mathrm{~s}^{-1}\right.$ for NEE, $0.0107 \pm 0.0074 \mathrm{~m} \mathrm{~s}^{-1}$ for $g_{\mathrm{s}}$ ) around mid-morning and then rapidly declined as VPD increased (Fig. 5d). In the late afternoon when VPD decreased, the NEE and $g_{\mathrm{s}}$ decreased and recovered slightly approaching conditions seen earlier during 


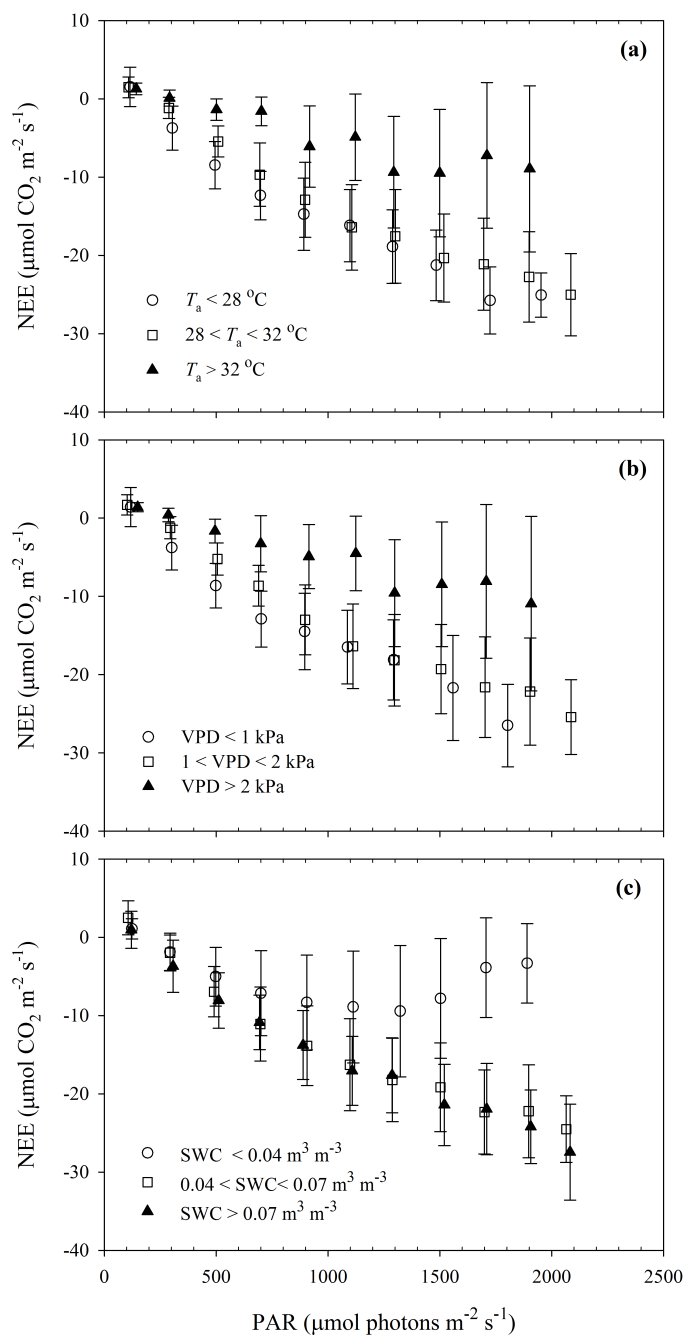

Fig. 4. Relationship between net ecosystem $\mathrm{CO}_{2}$ exchange (NEE) and photosynthetically active radiation (PAR) under (a) different air temperature $\left(T_{\mathrm{a}}\right),(\mathbf{b})$ different vapor pressure deficit (VPD), and (c) under different soil water content (SWC) during the peak growing stages (DOY 201-240). NEE data were averaged with PAR bins. Bin width is $200 \mu \mathrm{mol}$ photons $\mathrm{m}^{-2} \mathrm{~s}^{-1}$. Bars indicate standard deviations.

the day (Fig. 5d). The recovery of $g_{\mathrm{s}}$ was small because of the reduced plant transpiration and soil evaporation as both of these were limited by low soil water content (Fu et al., 2006). Early daytime peaks in NEE have been observed previously at Metolius (Anthoni et al., 1999) and in a California grassland (Valentini et al., 1995). Valentini (1995) indicated that afternoon stomatal closure can have a dramatic impact on the diurnal cycle of assimilation, resulting in an early morning peak in NEE, i.e. a response often enhanced during periods of low soil water content. This is consistent with theoretical studies of optimal stomatal control suggesting that afternoon $\mathrm{CO}_{2}$ uptake should be suppressed as soil drying progresses (Cowan, 1982)
The distinct hysteresis loop was evident in the relationship between NEE and PAR for both non-stress and waterstress days (Fig. 6a, b). However, the hysteresis loop was much reduced in area on the non-stress days when compared to water-stress days. On non-stress days, as PAR increased in the morning, NEE increased (gets more negative) reaching the peak value at the highest PAR of $2080 \mu \mathrm{mol}$ photons $\mathrm{m}^{-2} \mathrm{~s}^{-1}$ and as PAR decreased in the afternoon, NEE declined (Fig. 6a). The result suggests that $T_{\mathrm{a}}$, VPD, and SWC are not the limiting factors in the NEEPAR response. During water-stress conditions, as PAR increased in the morning, NEE increased, reaching the peak value at PAR of $1100 \mu \mathrm{mol}$ photons $\mathrm{m}^{-2} \mathrm{~s}^{-1}$ and then rapidly decreased, reaching almost zero at the end of morning. As PAR decreased, NEE remained constant nearly zero throughout the afternoon (Fig. 6b). Zeppel et al. (2004) explained that hysteresis occurs when an increase in an independent variable, $x$, does not cause the same response in a dependent variable, $y$, when the variable $x$ decreases. In the morning, as PAR increased, carbon uptake increased, but in the afternoon, carbon uptake at any given PAR was lower than the rate in the morning at the same PAR.

The diurnal pattern of NEE depends on the interaction between the atmosphere and physiological response. Körner (1995) attributed the asymmetric (hysteresis) shape of the diurnal cycle of NEE during dry periods with high VPD to a limitation of photosynthesis due to stomatal closure at high VPD or to enhanced respiration induced by high temperatures. Moreover, a wide range of studies have shown that ecosystem respiration also exhibits hysteresis. This may be attributed either to the fact that temperature is out of phase between the different levels from leaf to deep soil (GaumontGuay et al., 2006; Graf et al., 2008; Pingintha et al., 2010), to a lagged response of root respiration to light (Tang et al., 2005), or both (Bahn et al., 2008). In the present study, the daytime NEE data obtained during non-stress and waterstress days was compiled using different bins of $T_{\mathrm{a}}$ and VPD. Bin width was $2^{\circ} \mathrm{C}$ for $T_{\mathrm{a}}$ and $0.5 \mathrm{kPa}$ for VPD, respectively. The NEE data were averaged over each bin regardless of PAR, and then were plotted against $T_{\mathrm{a}}$ and VPD in Fig. 7a and Fig. 7b, respectively. Clearly, under non-stress conditions, NEE almost linearly increased as $T_{\mathrm{a}}$ (Fig. 7a) and VPD (Fig. 7b) increased. In contrast, under water-stress conditions, NEE increased with $T_{\mathrm{a}}$ until approximately $29^{\circ} \mathrm{C}$, then decreased with any additional increase in $T_{\mathrm{a}}$ (Fig. 7a). Similarly, NEE also increased with increasing VPD and decreased as VPD above $1.2 \mathrm{kPa}$ (Fig. $7 \mathrm{~b}$ ).

Bhagsari et al. (1976) observed large reductions in photosynthesis and stomatal conductance as the relative water content of peanut leaves decreased from 80 to $75 \%$. They further concluded that the main effect of a soil water deficit on leaf carbon exchange rate is exerted through stomatal closure. Reddy et al. (2003) reported also a decrease in leaf mesophyll conductance during water stress. This feature has been suggested to be of importance as water stress increases, 

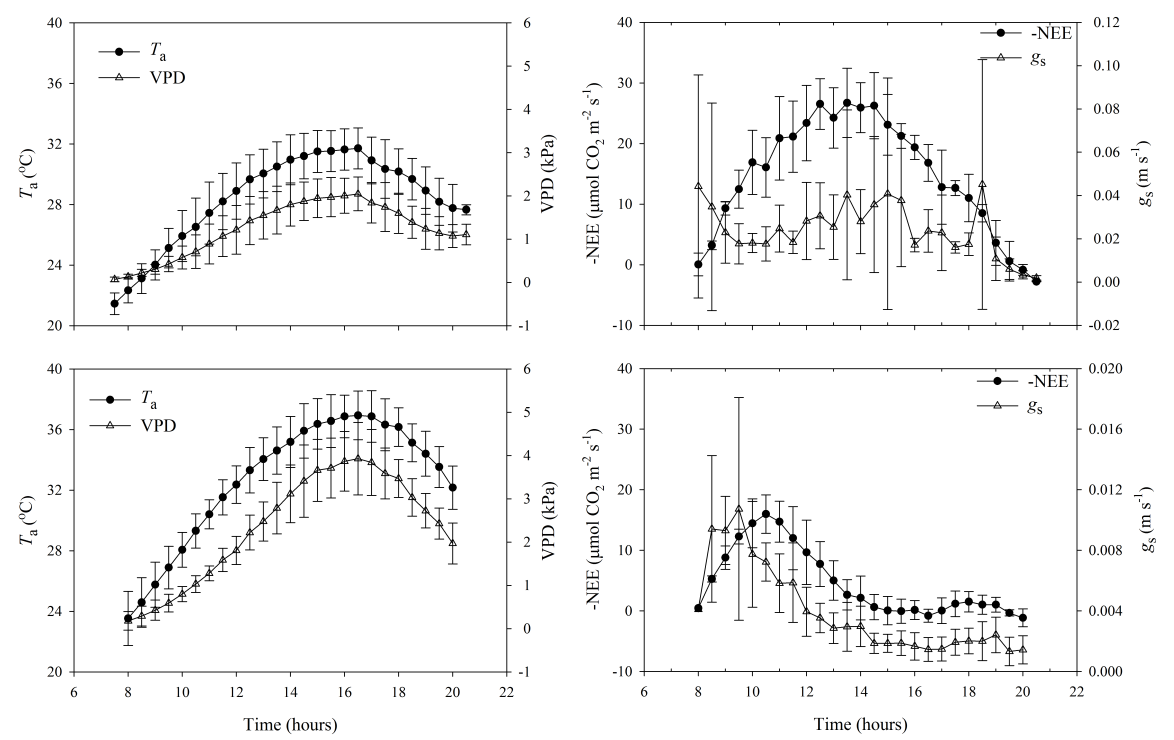

Fig. 5. Diurnal variations of negative net ecosystem $\mathrm{CO}_{2}$ exchange (-NEE), surface conductance $\left(g_{\mathrm{s}}\right)$ and correspondingly environmental factors of air temperature $\left(T_{\mathrm{a}}\right)$ and vapor pressure deficit (VPD) on clear days under non-stress conditions (a and $\mathbf{b}$, measured on DOY 210 , 212, 213, 214, and 216) and water-stress conditions (c and d, measured on DOY 220, 222, 225, 226, and 227). Bars indicate standard deviations.

because it limits the transfer of $\mathrm{CO}_{2}$ from the intercellular air spaces to the carboxylation sites (Bogi and Loreto, 1989) results in a reduction in photosynthesis. It is evident that the reduction of photosynthesis was related to the variation of $g_{\mathrm{s}}$ with water-stress (Anthoni et al., 2002; Aires et al., 2008b). In our case, under water-stress days without the limitation of PAR $\left(>1000 \mu\right.$ mol photons $\left.\mathrm{m}^{-2} \mathrm{~s}^{-1}\right)$, decreasing in $g_{\mathrm{s}}$ with increasing VPD was observed $\left(R^{2}=0.95\right.$; Fig. 8$)$. Considering the consequences of water stress, Oguntunde (2005) also found a strong correlation between canopy conductance and VPD in stressed cassava at non-limiting solar radiation. The observed decrease in $g_{\mathrm{s}}$ with increasing VPD corresponds to a decrease in carbon uptake, indicating strong stomatal control. These results inferred that during times when plants were subject to water stress, the afternoon NEE decreased caused by a limitation of photosynthesis due to stomatal closure at high VPD. Furthermore, since ecosystem respiration, a significant fraction of NEE, typically increases with temperature (e.g. Reichstein et al., 2005; Fu et al., 2006; Wang et al., 2008), the higher afternoon temperatures may have led to a decrease in NEE during that time of day (Fu et al., 2006). We can then infer that the suppression of NEE in the peanut ecosystem during periods of water stress resulting from a limitation of photosynthesis attributed to stomatal closure at high VPD and enhanced respiration due to high temperature, is responsible for a large of hysteresis loop. The consistent presence of hysteresis appears to limit the ability of the Michaelis-Menten function to adequately predict daytime NEE as a function of PAR. Future work should be done to construct a gap-filling model that takes into account temperature and vapor pressure deficit, both variables of significance

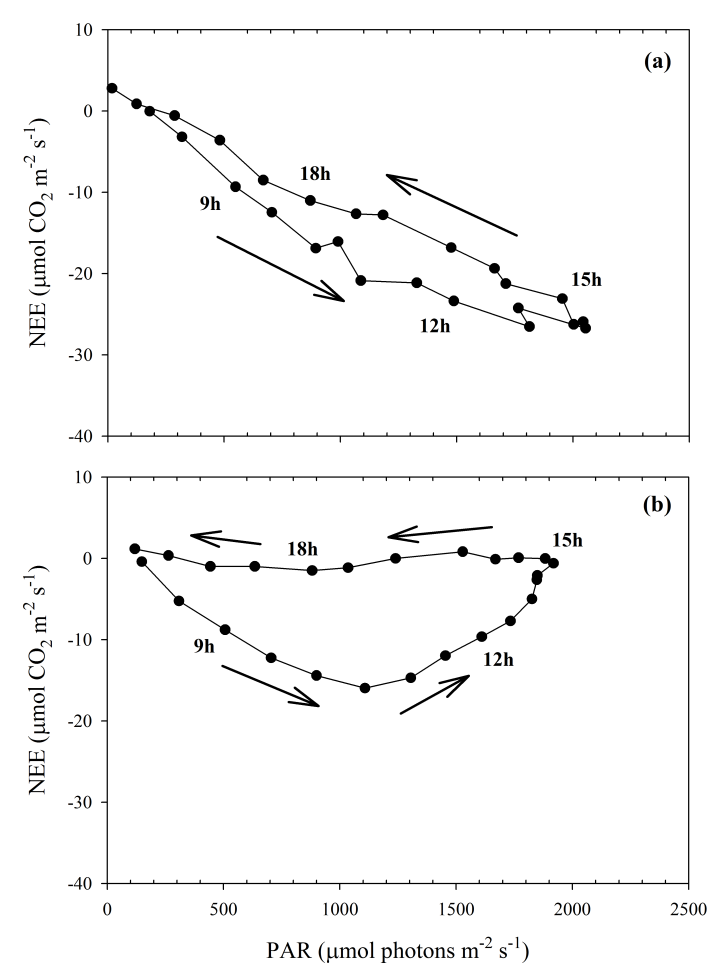

Fig. 6. The relationship between photosynthetically active radiation (PAR) and net ecosystem $\mathrm{CO}_{2}$ exchange (NEE) on clear days under (a) non-stress conditions (measured on DOY 210, 212, 213, 214, and 216) and (b) water-stress conditions (measured on DOY 220, $222,225,226$, and 227). The arrows indicate the direction of the hysteresis effect. 

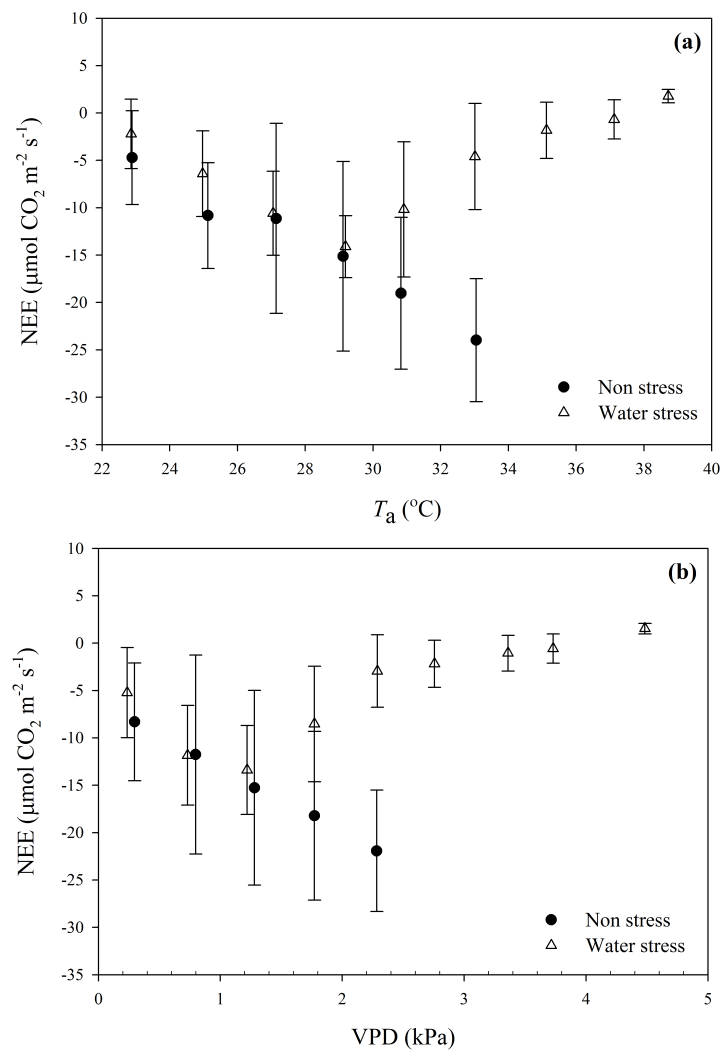

Fig. 7. The response of net ecosystem $\mathrm{CO}_{2}$ exchange (NEE) to (a) air Temperature $\left(T_{\mathrm{a}}\right)$ and (b) vapor pressure deficit (VPD) on clear days under non-stress conditions (measured on DOY 210, 212, 213, 214, and 216) and water-stress conditions (measured on DOY 220, 222, 225, 226, and 227). NEE was bin averaged. Bin size was $2{ }^{\circ} \mathrm{C}$ for $T_{\mathrm{a}}$ and $0.5 \mathrm{kPa}$ for $\mathrm{VPD}$, respectively. Bars indicate standard deviations.

in water-stressed conditions, and apply these finding to other ecosystems.

\section{Conclusions}

We quantified NEE and its response to drought stress over a rainfed peanut field during the growing season using the eddy-covariance method. PAR was the primary driver controlling daytime NEE, accounting for 67 to $89 \%$ of the variations in NEE during the peanut growing season. However, Michaelis-Menten model describing NEE during daytime as a function of PAR could not be used during portions of the peak growing stage, indicating that other environmental variables became proportionally more important in controlling NEE during these periods. We found that, for very low soil water content conditions ( $\mathrm{SWC}<0.04 \mathrm{~m}^{3} \mathrm{~m}^{-3}$ ), NEE significantly decreased when PAR values exceeded $1300 \mu \mathrm{mol}$ photons $\mathrm{m}^{-2} \mathrm{~s}^{-1}$. Results suggest that soil water content was the dominant factor limiting the NEE-PAR response of peanut during the peak growing stage.

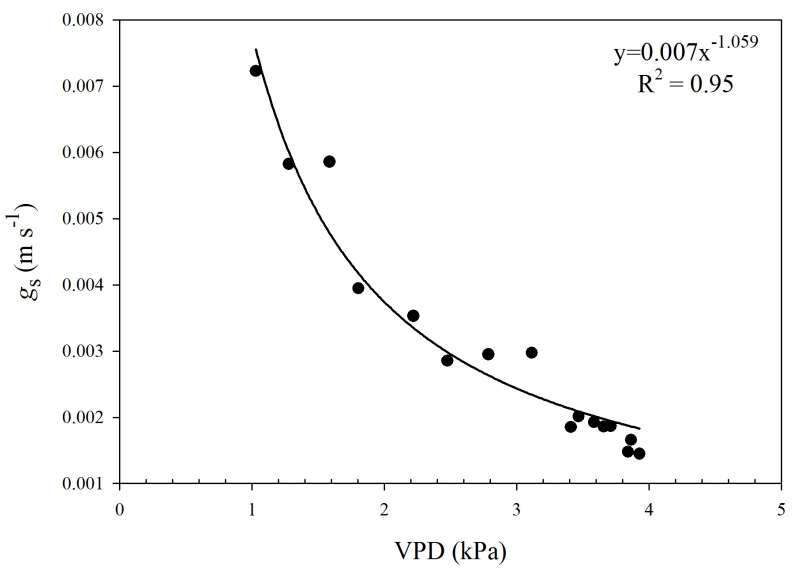

Fig. 8. Response of half-hourly surface conductance $\left(g_{\mathrm{s}}\right)$ to vapor pressure deficit (VPD) during water-stress condition (measured on DOY 220, 222, 225, 226, and 227) when PAR $>1000 \mu \mathrm{mol}$ photons $\mathrm{m}^{-2} \mathrm{~s}^{-1}$.

A pronounced hysteresis in NEE was observed in both non-stress and water-stress conditions as a function of PAR. However, the magnitude of hysteresis was much larger during water-stress days than non-stress days. NEE was suppressed under high air temperature and vapor pressure deficit during periods of water stress due to higher ecosystem respiration at high temperatures and stomatal limitation of photosynthesis at high vapor pressure deficit.

The resultant large hysteresis loop leads to the failure of the Michaelis-Menten function in describing the NEE-PAR relationship. Previous studies have described the effect of high vapor pressure deficit and temperature on net ecosystem $\mathrm{CO}_{2}$ exchange, but the characterization of these variables impact being linked through hysteresis is largely unexplored. This research will aid in developing more robust gap filling methodologies. Further studies of water-limited ecosystems are needed to develop improved models during these extreme environmental conditions to more reliably predict long-term NEE. This in turn should lead to improvements in our estimation of the global carbon balance.

Acknowledgements. This research was funded by the US Department of Energy, Office of Science, grant DE-FG0206ER64321. We would like to thank the Royal Golden Jubilee (RGJ) Ph.D. program of Thailand Research Fund (TRF) and Chiang Mai University for providing a research scholarship. We wish to gratefully acknowledge the Georgia Peanut Commission and the National Peanut Board for their precious support leading to the present experiment. We sincerely acknowledge Cross's family for their patient and sustained logistical support in conducting this research on the premises. A special thank goes to Ian Flitcroft for his editorial input.

Edited by: V. Brovkin 


\section{References}

Aires, L. M., Pio, C. A., and Pereira, J. S.: The effect of drought on energy and water vapour exchange above a mediterranean $\mathrm{C} 3 / \mathrm{C} 4$ grassland in southern portugal, Agr. Forest Meteorol., 148, 565579, 2008a.

Aires, L. M. I., Pio, C. A., and Pereira, J. S.: Carbon dioxide exchange above a mediterranean $\mathrm{C} 3 / \mathrm{C} 4$ grassland during two climatologically contrasting years, Glob. Change Biol., 14, 539555, 2008 b.

Anthoni, P. M., Law, B. E., and Unsworth, H. M. H.: Carbon and water vapor exchange of an open-canopied ponderosa pine ecosystem, Agr. Forest Meteorol., 95, 151-168, 1999.

Anthoni, P. M., Unsworth, M. H., Law, B. E., Irvine, J., Baldocchi, D. D., Tuyl, S. V., and Moore, D.: Seasonal differences in carbon and water vapor exchange in young and old-growth ponderosa pine ecosystems, Agr. Forest Meteorol., 111, 203-222, 2002.

Aubinet, M., Grelle, A., Ibrom, A., Rannik, U., Moncrieff, J., Foken, T., Kowalski, A. S., Martin, P. H., Berbigier, P., Bernhofer, C., Clement, R., Elbers, J., Granier, A., Grunwald, T., Morgenstern, K., Pilegaard, K., Rebmann, C., Snijders, W., Valentini, R., and Vesala, T.: Estimates of the annual net carbon and water exchange of forests: The euroflux methodology, Adv. Ecol. Res., 30, 113-175, 2000.

Bahn, M., Rodeghiero, M., Anderson-Dunn, M., Dore, S., Gimeno, C., Drösler, M., Williams, M., Ammann, C., Berninger, F., Flechard, C., Jones, S., Balzarolo, M., Kumar, S., Newesely, C., Priwitzer, T., Raschi, A., Siegwolf, R., Susiluoto, S., Tenhunen, J., Wohlfahrt, G., and Cernusca, A.: Soil respiration in european grasslands in relation to climate and assimilate supply, Ecosystems, 11, 1352-1367, 2008.

Baldocchi, D. D., Falge, E., Gu, L. H., Olson, R., Hollinger, D., Running, S., Anthoni, P., Bernhofer, C., Davis, K., Evans, R., Fuentes, J., Goldstein, A., Katul, G., Law, B., Lee, X. H., Malhi, Y., Meyers, T., Munger, W., Oechel, W., U, K. T. P., Pilegaard, K., Schmid, H. P., Valentini, R., Verma, S., Vesala, T., Wilson, K., and Wofsy, S.: Fluxnet: A new tool to study the temporal and spatial variability of ecosystem-scale carbon dioxide, water vapor, and energy flux densities, B. Am. Meteorol. Soc., 82, 2415-2434, 2001.

Bhagsari, A. S., Brown, R. H., and Schepers, J. S.: Effect of moisture stress on photosynthesis and some related physiological characteristics in peanut, Crop Sci., 16, 712-715, 1976.

Bogi, G. and Loreto, F.: Gas-exchange properties of salt stressed olive (Olea europea L.) leaves, Plant Physiol., 90, 1408-1416, 1989.

Braswell, B. H., Sacks, W. J., Linder, E., and Schimel, D. S.: Estimating diurnal to annual ecosystem parameters by synthesis of a carbon flux model with eddy covariance net ecosystem exchange observations, Glob. Change Biol., 11, 335-355, 2005.

Chapin, F., Woodwell, G., Randerson, J., Rastetter, E., Lovett, G., Baldocchi, D., Clark, D., Harmon, M., Schimel, D., Valentini, R., Wirth, C., Aber, J., Cole, J., Goulden, M., Harden, J., Heimann, M., Howarth, R., Matson, P., McGuire, A., Melillo, J., Mooney, H., Neff, J., Houghton, R., Pace, M., Ryan, M., Running, S., Sala, O., Schlesinger, W., and Schulze, E. D.: Reconciling carbon-cycle concepts, terminology, and methods, Ecosystems, 9, 1041-1050, 2006.

Chapman, S. C., Ludlow, M. M., Blamey, F. P. C., and Fischer, K. S.: Effect of drought during pod filling on utilization of water and on growth of cultivars of groundnut (Arachis hypogaea L.), Field Crops Res., 32, 243-255, 1993a.

Chapman, S. C., Ludlow, M. M., Blamey, F. P. C., and Fischer, K. S.: Effect of drought during early reproductive development on growth of cultivars of groundnut (Arachis hypogaea L.) .1. Utilization of radiation and water during drought, Field Crops Res., 32, 193-210, 1993b.

Clifford, S. C., Stronach, I. M., Mohamed, A. D., Azam-Ali, S. N., and Crout, N. M. J.: The effects of elevated atmospheric carbon dioxide and water stress on ligth interception, dry matter production and yield in stands of groundnut (Arachis hypogaea L.), J. Exp. Bot., 44, 1763-1770, 1993.

Collino, D. J., Dardanelli, J. L., Sereno, R., and Racca, R. W.: Physiological responses of argentine peanut varieties to water stress. Light interception, radiation use efficiency and partitioning of assimilates, Field Crops Res., 70, 177-184, 2001.

Cowan, I. R.: Regulation of water use in relation to carbon gain in higheer plants, in: Physiological plant ecology, edited by: Lange, O. L., Nobel, P. S., Osmond, C. B., and Zeigler, H., SpringerVerlag, Berlin, 589-613, 1982.

Falge, E., Baldocchi, D., Olson, R., Anthoni, P., Aubinet, M., Bernhofer, C., Burba, G., Ceulemans, R., Clement, R., Dolman, H., Granier, A., Gross, P., Grunwald, T., Hollinger, D., Jensen, N. O., Katul, G., Keronen, P., Kowalski, A., Lai, C. T., Law, B. E., Meyers, T., Moncrieff, H., Moors, E., Munger, J. W., Pilegaard, K., Rannik, U., Rebmann, C., Suyker, A., Tenhunen, J., Tu, K., Verma, S., Vesala, T., Wilson, K., and Wofsy, S.: Gap filling strategies for defensible annual sums of net ecosystem exchange, Agr. Forest Meteorol., 107, 43-69, 2001.

Fu, Y. L., Yu, G. R., Sun, X. M., Li, Y. N., Wen, X. F., Zhang, L. M., Li, Z. Q., Zhao, L., and Hao, Y. B.: Depression of net ecosystem $\mathrm{CO}_{2}$ exchange in semi-arid leymus chinensis steppe and alpine shrub, Agr. Forest Meteorol., 137, 234-244, doi:10.1016/j.agrformet.2006.02.009, 2006.

Gaumont-Guay, D., Black, T. A., Griffis, T. J., Barr, A. G., Jassal, R. S., and Nesic, Z.: Interpreting the dependence of soil respiration on soil temperature and water content in a boreal aspen stand, Agr. Forest Meteorol., 140, 220-235, 2006.

Goulden, M. L.: Carbon assimilation and water-use efficiency by neighboring mediterranean-climate oaks that differ in water access, Tree Physiol., 16, 417-424, 1996.

Goulden, M. L., Daube, B. C., Fan, S.-M., Sutton, D. J., Bazzaz, A., Munger, J. W., and Wofsy, S. C.: Physiological responses of a black spruce forest to weather, J. Geophys. Res., 102, 2898728996, doi:10.1029/97JD01111, 1997.

Graf, A., Weihermüller, L., Huisman, J. A., Herbst, M., Bauer, J., and Vereecken, H.: Measurement depth effects on the apparent temperature sensitivity of soil respiration in field studies, Biogeosciences, 5, 1175-1188, 2008, http://www.biogeosciences.net/5/1175/2008/.

Hastings, S. J., Oechel, W. C., and Muhlia-Melo, A.: Diurnal, seasonal and annual variation in the net ecosystem $\mathrm{CO}_{2}$ exchange of a desert shrub community (sarcocaulescent) in baja california, mexico, Glob. Change Biol., 11, 927-939, 2005.

Holst, J., Barnard, R., Brandes, E., Buchmann, N., Gessler, A., and Jaeger, L.: Impacts of summer water limitation on the carbon balance of a scots pine forest in the southern upper rhine plain, Agr. Forest Meteorol., 148, 1815-1826, doi:10.1016/j.agrformet.2008.06.008, 2008. 
Hui, D. F., Wan, S. Q., Su, B., Katul, G., Monson, R., and Luo, Y. Q.: Gap-filling missing data in eddy covariance measurements using multiple imputation (mi) for annual estimations, Agr. Forest Meteorol., 121, 93-111, doi:10.1016/S0168-1923(03)001588, 2004.

IPCC: Climate change 2007: The physical science basic, edited by: Solomon, S., Qin, D., Manning, M., Chen, Z., Marquis, M., Averyt, K. B., Tignor, M., and Miller, H. L., Cambridge University Press, New York, USA, 996 pp., 2007.

Körner, C.: Leaf diffusive conductances in the major vegetation types of globe, in: Ecophysiology of photosynthesis, edited by: Schulze, E. D. and Caldwell, M. M., Springer, Berlin, 463-490, 1995.

Lauriano, J. A., Ramalho, J. C., Lidon, F. C., and do Céu Matos, M.: Peanut photosynthesis under drought and re-watering, Photosynthetica, 42, 37-41, 2004.

Law, B. E., Falge, E., Gu, L., Baldocchi, D. D., Bakwin, P., Berbigier, P., Davis, K., Dolman, A. J., Falk, M., Fuentes, J. D., Goldstein, A., Granier, A., Grelle, A., Hollinger, D., Janssens, I. A., Jarvis, P., Jensen, N. O., Katul, G., Mahli, Y., Matteucci, G., Meyers, T., Monson, R., Munger, W., Oechel, W., Olson, R., Pilegaard, K., Paw, K. T., Thorgeirsson, H., Valentini, R., Verma, S., Vesala, T., Wilson, K., and Wofsy, S.: Environmental controls over carbon dioxide and water vapor exchange of terrestrial vegetation, Agr. Forest Meteorol., 113, 97-120, doi:10.1016/S01681923(02)00104-1, 2002.

Li, S. G., Asanuma, J., Eugster, W., Kotani, A., Liu, J. J., Urano, T., Oikawa, T., Davaa, G., Oyunbaatar, D., and Sugita, M.: Net ecosystem carbon dioxide exchange over grazed steppe in central mongolia, Glob. Change Biol., 11, 1941-1955, doi:10.1111/j.1365-2486.2005.01047.x, 2005.

Meyers, T. P. and Hollinger, S. E.: An assessment of storage terms in the surface energy balance of maize and soybean, Agr. Forest Meteorol., 125, 105-115, 2004.

Michaelis, L. and Menten, M. L.: Die kinetik der invertinwirkung, Biochem. Z., 49, 333-369, 1913.

Monteith, J. L. and Unsworth, M. H.: Principles of environmental physics, Edward Arnold, London, 291 pp., 1990.

Nautiyal, P. C., Ravindra, V., and Joshi, Y. C.: Gas-exchange and leaf water relations in 2 peanut cultivars of different drought tolerance, Biol. Plantarum, 37, 371-374, 1995.

Oguntunde, P.: Whole-plant water use and canopy conductance of cassava under iimited available soil water and varying evaporative demand, Plant Soil, 278, 371-383, 2005.

Ooba, M., Hirano, T., Mogami, J.-I., Hirata, R., and Fujinuma, Y.: Comparisons of gap-filling methods for carbon flux dataset: A combination of a genetic algorithm and an artificial neural network, Ecol. Model., 198, 473-486, 2006.

Papale, D. and Valentini, R.: A new assessment of european forests carbon exchanges by eddy fluxes and artificial neural network spatialization, Glob. Change Biol., 9, 525-535, 2003.

Papale, D., Reichstein, M., Aubinet, M., Canfora, E., Bernhofer, C., Kutsch, W., Longdoz, B., Rambal, S., Valentini, R., Vesala, T., and Yakir, D.: Towards a standardized processing of Net Ecosystem Exchange measured with eddy covariance technique: algorithms and uncertainty estimation, Biogeosciences, 3, 571-583, 2006,

http://www.biogeosciences.net/3/571/2006/.

Pingintha, N., Leclerc, M. Y., Beasley., J. P., Zhang, G., and Sen- thong, C.: Assessment of the soil $\mathrm{CO}_{2}$ gradient method for soil $\mathrm{CO}_{2}$ efflux measurements: Comparison of six models in the calculation of the relative gas diffusion coefficient, Tellus B, 62, 47-58, 2010

Reddy, T. Y., Reddy, V. R., and Anbumozhi, V.: Physiological responses of groundnut (Arachis hypogeae L.) to drought stress and its amelioration: A critical review, Plant Growth Regul., 41, 75-88, 2003.

Reichstein, M., Falge, E., Baldocchi, D., Papale, D., Aubinet, M., Berbigier, P., Bernhofer, C., Buchmann, N., Gilmanov, T., Granier, A., Gr?nwald, T., Havránková, K., Ilvesniemi, H., Janous, D., Knohl, A., Laurila, T., Lohila, A., Loustau, D., Matteucci, G., and Meyers, T.: On the separation of net ecosystem exchange into assimilation and ecosystem respiration: Review and improved algorithm, Glob. Change Biol., 11, 1424-1439, 2005.

Ruimy, A., Jarvis, P. G., Baldocchi, D. D., Saugier, B., Begon, M., and Fitter, A. H.: $\mathrm{CO}_{2}$ fluxes over plant canopies and solar radiation: A review, in: Adv. Ecol. Res., Academic Press, 1-68, 1995.

Saxena, N. P., Natrajan, M., and Reddy, M. S.: Chickpea, pigeonpea, and groundnut, in: Potential productivity of field crops under different environments, edited by: Smith, W. H. and Banta, S. J., IRRI, Los Banos, Philippines, 281-305, 1983.

Schmid, H. P.: Source areas for scalars and scalar fluxes, Bound.Lay. Meteorol., 67, 293-318, 1994.

Serrano-Ortiz, P., Kowalski, A., Domingo, F., Rey, A., Pegoraro, E., Villagarcía, L., and Alados-Arboledas, L.: Variations in daytime net carbon and water exchange in a montane shrubland ecosystem in southeast spain, Photosynthetica, 45, 30-35, 2007.

Sims, P. L. and Bradford, J. A.: Carbon dioxide fluxes in a southern plains prairie, Agr. Forest Meteorol., 109, 117-134, 2001.

Suyker, A. E. and Verma, S. B.: Year-round observations of the net ecosystem exchange of carbon dioxide in a native tallgrass prairie, Glob. Change Biol., 7, 279-289, 2001.

Suyker, A. E., Verma, S. B., Burba, G. G., Arkebauer, T. J., Walters, D. T., and Hubbard, K. G.: Growing season carbon dioxide exchange in irrigated and rainfed maize, Agr. Forest Meteorol., 124, 1-13, 2004.

Tang, J., Baldocchi, D. D., and Xu, L.: Tree photosynthesis modulates soil respiration on a diurnal time scale, Glob. Change Biol., 11, 1298-1304, 2005.

Valentini, R., Gamon, J. A., and Field, C. B.: Ecosystem gas exchange in a california grassland: Seasonal patterns and implications for scaling, Ecology, 76, 1940-1952, 1995.

Vickers, D. and Mahrt, L.: Quality control and flux sampling problems for tower and aircraft data, J. Atmos. Ocean. Tech., 14, 512 526, 1997.

Wang, Y. L., Zhou, G. S., and Wang, Y. H.: Environmental effects on net ecosystem $\mathrm{CO}_{2}$ exchange at half-hour and month scales over stipa krylovii steppe in northern china, Agr. Forest Meteorol., 148, 714-722, doi:10.1016/j.agrformet.2008.01.013, 2008.

Webb, E. K., Pearman, G. I., and Leuning, R.: Correction of flux measurements for density effects due to heat and water-vapor transfer, Q. J. Roy. Meteor. Soc., 106, 85-100, 1980.

Wilczak, J., Oncley, S., and Stage, S.: Sonic anemometer tilt correction algorithms, Bound.-Lay. Meteorol., 99, 127-150, 2001.

Wilson, K., Goldstein, A., Falge, E., Aubinet, M., Baldocchi, D., Berbigier, P., Bernhofer, C., Ceulemans, R., Dolman, H., Field, 
C., Grelle, A., Ibrom, A., Law, B. E., Kowalski, A., Meyers, T., Moncrieff, J., Monson, R., Oechel, W., Tenhunen, J., Valentini, R., and Verma, S.: Energy balance closure at fluxnet sites, Agr. Forest Meteorol., 113, 223-243, 2002.
Zeppel, M. J. B., Murray, B. R., Barton, C., and Eamus, D.: Seasonal responses of xylem sap velocity to vpd and solar radiation during drought in a stand of native trees in temperate australia, Funct. Plant Biol., 31, 461-470, doi:10.1071/Fp03220, 2004. 